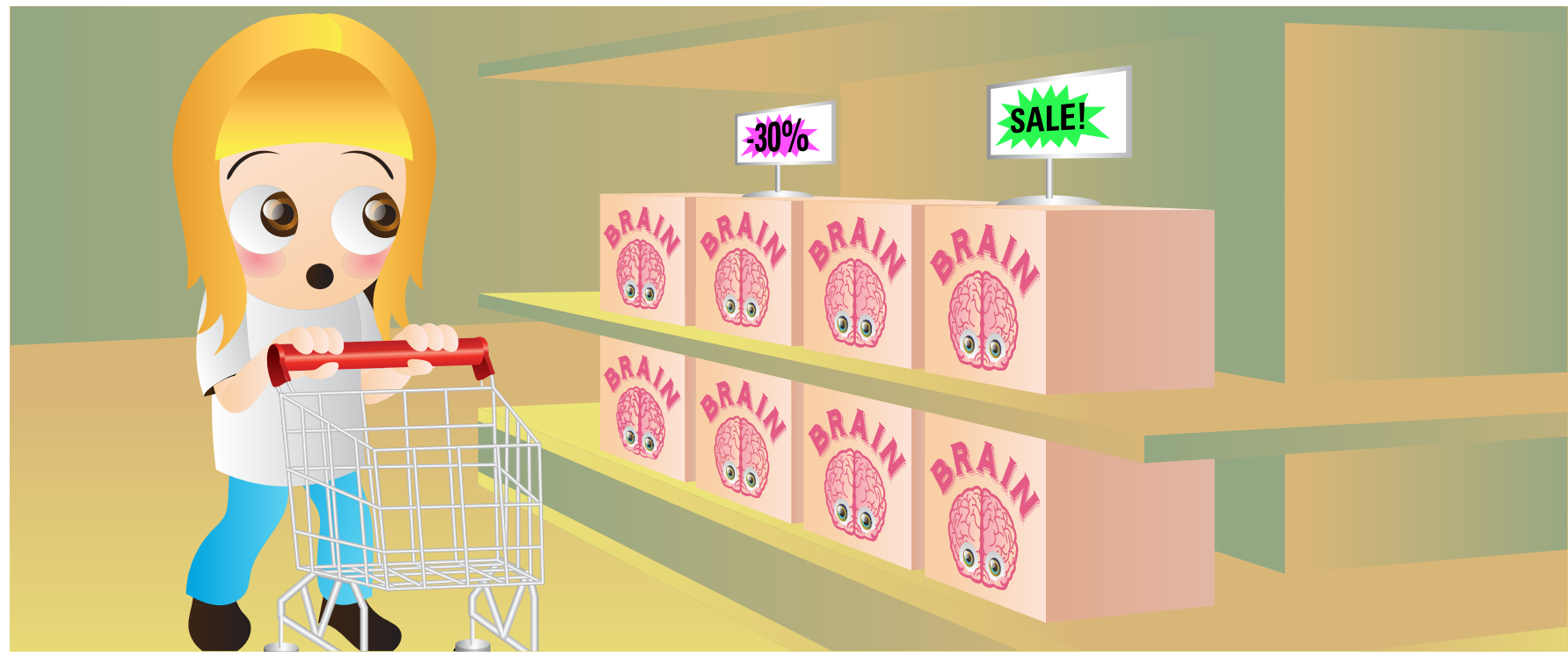

\title{
CAN MONEY BUY YOU A BETTER BRAIN? WHAT DO YOU THINK?
}

\section{Kristina Uban ${ }^{1,2}$, Megan Herting ${ }^{1,2}$ and Elizabeth R. Sowel1 ${ }^{1,2^{*}}$}

${ }^{1}$ Division of Research on Children, Youth, and Families, Children's Hospital Los Angeles, Los Angeles, CA, USA, ${ }^{2}$ Department of Pediatrics, Keck School of Medicine, University of Southern California, Los Angeles, CA, USA

REVIEWED BY:

CARPENTER

COMMUNITY

CHARTER

SCHOOL

10-11 YEARS OLD
The things you do and experience in the environment you grow up in as a child can impact the way your brain develops and works throughout your life. Our brains keep changing as we learn new skills and form new memories, even when we get to be older adults. When we are in our childhood and teenage years, our brains are like sponges, soaking up things we learn, see, eat, and do at a much faster rate than later in life. If you spend all of your time doing nothing when you are a kid, then, your brain will have nothing to tell it how to wire itself as you grow up. So, it is important that you give your brain a chance to experience new activities like sports, art, and music, to learn new things from reading books or going to museums, and to make new friends to play and learn with. You do not need a lot of money to do many of these things, so get off of the couch and start training your brain!

Imagine that your family was given a million dollars. How would your life change? Where would you live? What would you spend your time doing? What would you and your family buy? Now, imagine how your life would be if your family did not have very much money. How different are the lives of children with lots of money compared with the lives of children without 


\section{FIGURE 1}

On the left is a picture of a "Brain Bank" with money being deposited into the slot.

The money represents the kinds of experiences we give our brain. On the right is a picture of an imaginary brain with all sorts of words and images that illustrate the kinds of things that shape the way our brains develop. We have no control over some of the things that change our brains, like the hormones that affect our bodies through puberty and are different for boys and girls, and the genes that we inherit from our mothers and fathers. However, there are some things we can control that also shape the way our brains grow, like the kinds of foods we choose to eat, the activities we choose to do, including sports, music, and spending time at school and with friends and family (original drawings and graphic artwork by Elizabeth Sowell and James Jackson Crowell). very much money? Not only would the type of home a child lives in and the type of food a child eats be different but even everyday habits and activities would likely be different for a child who had a lot versus only a little bit of money. Around the world, there are countries that have a lot of money and countries that do not. Even in the United States, there are big differences in the type of jobs people have and how much money they can earn, which can have an impact on where they live and what experiences they have on a dayto-day basis. Scientists who study the brain know that the things kids do and experience every day can influence their brains, and that many experiences that help kids' brains work and grow better are completely free (see Figure 1).

In this paper, we talk about findings from a recent article showing that the size of the brain's surface is bigger in children whose families make a lot of money compared with the size of the brain's surface in children whose families make less money [1]. We studied over 1,000 normal kids and teenagers between 3 and 20 years old using a technique called magnetic resonance imaging (MRI). MRI uses a big donut-shaped magnet to create detailed pictures of the insides of the body, and MRI can be used to look at the brain and measure its shape and size. We also used special computer games, which are actually tests that measure kids' thinking ability. We found that, on average, the brain surface is approximately $6 \%$ smaller in kids whose families earn $\$ 25,000$ a year or less, compared with kids whose families earn $\$ 150,000$ a year or more (see the blue line in Figure 2A) [1]. Kids whose families make more money have better scores on tests that measure thinking and decision-making abilities, and the larger size of their brain surface helps us explain this observation. Another important thing that we found is that some of the kids with the lowest family income have brains the same size as some of the kids with the most money. Similarly, some of the kids in the highest income families have brains the same size as kids with the lowest family income. Why would this be? While we do not know for sure, it seems possible that having money is not as important as what your family spends their money on. That is, the kinds of experiences kids have, such as the activities they participate in and the foods they choose to eat, might be more important overall than the amount of money their families

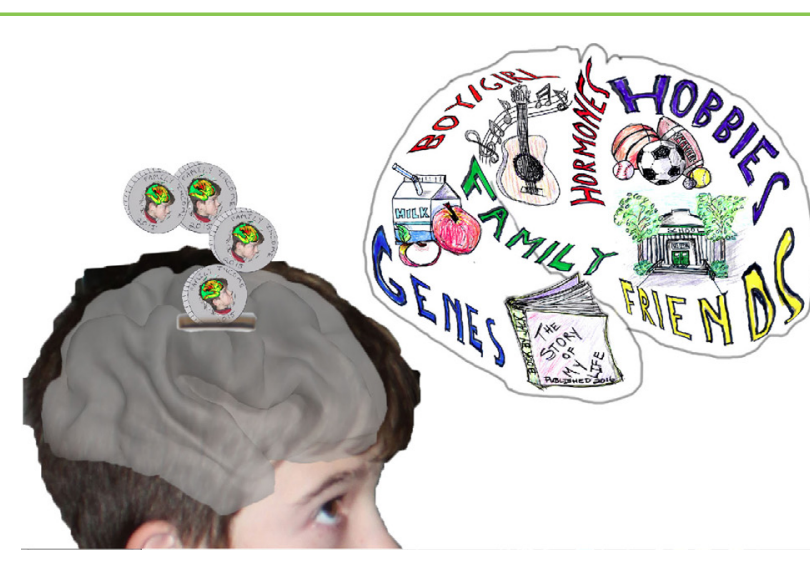

FIGURE 


\section{FIGURE 2}

Each black dot represents one person from each of our studies, and each of these people had an MRI of their brain.

Looking at the pattern of all of the dots combined in each graph tells us about the relationships between two pieces of information for each person. A. The relationship between family income in dollars-per-year and brain surface area among approximately 1,000 children and teenagers aged 3-20 years. On this graph, each dot tells you about the relationship between one person's family income (along the bottom line of the graph) and the same person's brain surface area (along the left side of the graph). B. The relationship between age and cortical thickness in the part of the brain that develops rapidly during childhood and teenage years in approximately 100 individuals between 7 and 60 years old. On this graph, each dot tells you about the relationship between one person's age (along the bottom line of the graph) and the same person's cortical thickness (along the left side of the graph). The blue lines in each graph show how more rapid changes occur in both the lower end of the family income range (in graph $\mathbf{A}$.) and the younger ages (in graph $\mathbf{B}$.), and the red lines in each graph show how slower changes occur with the higher levels of income $\mathbf{A}$., or with higher age $\mathbf{B}$. A. comes from a figure first appearing in Noble et al. [1], and B. comes from Sowell et al. [2]. have. We did not look at how families spend their money in this study, but it is an interesting area for future research.

The findings from this new study are important and add to our knowledge about how the young brain develops. Specifically, these findings tell us something about what is going on in the brain as it grows and wires cells together during childhood and the teen years. While our brains are always changing over time, every new skill we learn or memory we make changes our brains, even when we are much older (e.g., 40 or 50 years old, or, even 80 !). Some studies using MRI have shown changes in the brains of grown-ups after they learn new skills, like juggling, for example [3]. When we study animals such as rats or even monkeys, we can have a lot more control over their environments than we can with humans. These animal studies show that the brain develops differently in animals who grow up with interesting and new things to do in their environments, such as toys to play with, running wheels to exercise on, and other animals to interact with, compared with those animals that do not have these types of interesting experiences [4]. Animals that have a lot of things to do in their environments learn new things better than the animals that are raised in the "boring" environments that did not include toys, exercise, and social interactions. Why is this important to us humans? Because it tells us that the environment we grow up in (and the things that we choose to do and not to do) has a big impact on how our brains develop. Even though it is never too late to change our brains by learning new things, our brains are changing and developing a lot more rapidly during childhood and teenage years than they are later in life (see Figure 2B). So, what we do with our brains and bodies as children and teenagers could have a much bigger impact on how our brains actually develop and how they will work into our adulthood.

You might wonder, "What happens to the brain when we have interesting experiences?" Something must be changing in there among the special types of cells that make up the brain. While the brain is very complex, let us imagine it to be
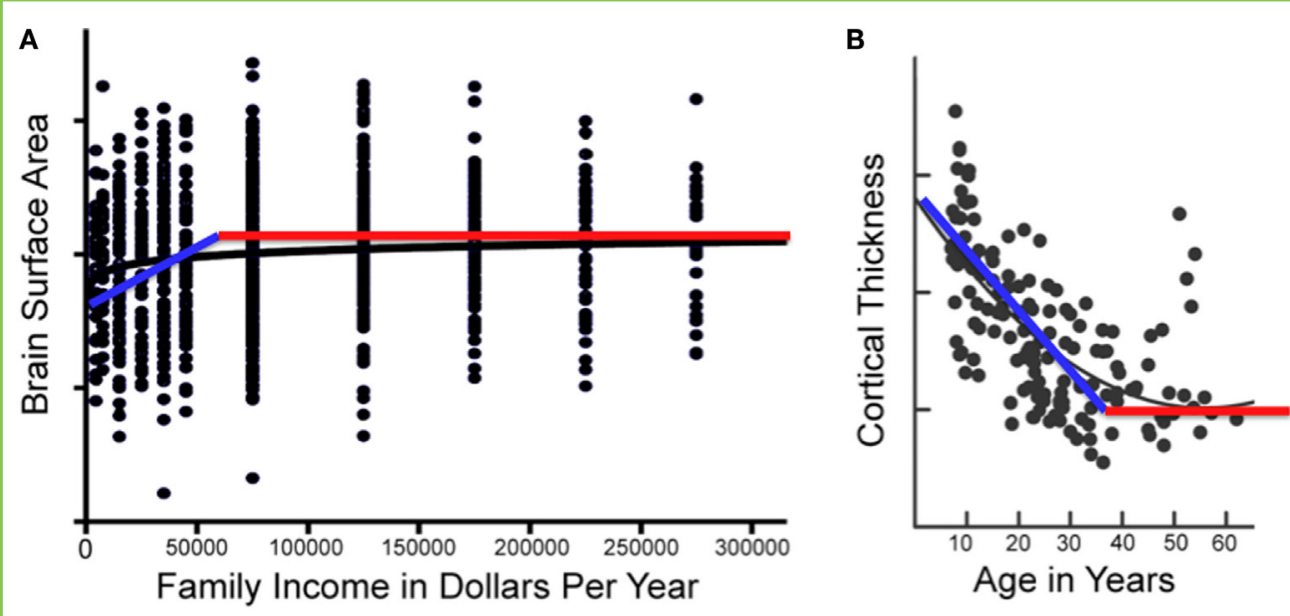

FIGURE 2 
CORTICAL

THICKNESS

Is a brain measurement that reflects the thickness of the outermost layers of the brain. The cortex of the brain is where all the brain cells (neurons) live and where the thinking happens. All of the brain cells in the cortex are connected by "wires" called axons. similar to the electrical connections in a house. It takes electricity to run lights and electronics in our home, just like it takes energy from the food we eat to keep connections in our brains alive and active. It would be wasteful and make no sense to keep every single light and electronic device in our home on all the time. We might want to have our electronics on when we need them, but, over time, some just become useless and not worth running or even keeping at all. Imagine if your family kept an electric typewriter on and plugged in even after computers became the most useful for typing and printing text? It would be pretty silly and a waste of both space and electricity, which are valuable resources. The same is true in your brain. You need different skills (encoded by brain cells and connections between them) when you are 4 years old compared with when you are 20 years old. You might need some of the brain cells and connections you have at age 4 to help you learn things as you get older (like the ones that will help you learn how to drive a car), but, it also does not make sense to keep a lot of brain cells "plugged in" for simple tasks that you have already mastered at age 4 , such as talking and walking. Your brain does all this by growing more cells and connections when you are young than you could possibly need as a grown up. Over time, as you learn, the brain removes or "un-plugs" the connections that are not used or needed, and strengthens the connections that you will need for the rest of your life. As you can see in Figure 2B (the blue line on the graph), when we measure the thickness of the brain's cortex, it actually decreases during the teenage years and into adulthood as unused connections go away, and other parts of the brain fill in the space in our skulls, making the connections we keep work better and faster. So, it makes sense that we help train our brains to determine which brain cells and connections to "plug in" and keep versus which to un-plug and give away, based on what we experience in our environment. If you want to learn more about how the brain develops, you should read another article in Frontiers for Young Minds called, "Building the Roads in the City of Your Brain" [5].

So, with this new information take a moment and ask yourself, "What am I doing, or what am I NOT doing to build my brain?" Think about your daily activities and habits and how they may help your brain to grow. For example, like animals that are able to exercise on running wheels, children and teens who do exercises such as running or swimming have a larger hippocampus the part of the brain important for learning and memory. Not surprisingly, exercise and physical activity have also been found to make it easier to learn some computer tasks [6] and other new information [6]. So, sitting on the couch and watching cartoons most of your time might not be the smartest choice for building the best brain!

Social play, which means having fun with other people, is important as we develop our brains. Maybe you and your friends like to build with Legos, play dress-up, do arts and crafts, or compete in sports or board games with each other. All of this is social play. Social play is not just fun and games - it is also very important for healthy brain development. Animal studies have shown 
that social play changes the amount of certain chemicals in the brain in a way that makes the brain stronger and healthier later in life [7]. Likewise, in humans, social play has been shown to help children learn new things more easily throughout life. Kids learn many critical social and thinking skills while they play with friends. These skills include the ability to solve problems and the ability to speak clearly and understand what other people say, as well as improved reading and math skills. Just think of it, you are playing with friends AND setting up your brain for success! But how does the amount of money a family has impact social play? Studies have found that kids from families with very little money have less free time to play, fewer outdoor places to play safely, and less creative activities in school and at home compared with kids from families with a lot of money [8]. So, it is clear that safe social play in school and at home is important for all kids and their developing brains, regardless of whether they have a lot of money or not very much to spend.

We wrote this article because we wanted kids to know that their brains need to experience lots of different things to grow and develop in the best possible way, and, having lots of money is not necessarily required for brain development. While we still do not really know why brain development and money are connected, we do know that our brains develop over time and that our brains keep changing as we learn new things, even into old age. The big, fast changes that occur in the brain during childhood and the teenage years make our brains very open to learning new skills, so it is all the more important that we "feed" our brains good experiences while we have a chance. Like exercise and social play, you might enjoy doing a lot of other things that are likely to help build your brain, such as playing a musical instrument, drawing, or learning a second language. Of course, there might be some daily activities you like more than others. Perhaps, you have favorite things you learn in school and other topics that are difficult or less fun to do. But learning new things, even when they are hard, is needed to build our brains. The take-home message is that while the amount of money your family has is related to the size of the brain's surface, everything you do (with or without using money) has an effect on the way your brain grows and develops.

\section{ORIGINAL ARTICLE REFERENCE}

Noble, K. G., Houston, S. M., Brito, N. H., Bartsch, H., Kan, E., Kuperman, J. M., et al. 2015. Family income, parental education and brain structure in children and adolescents. Nat. Neurosci. 18(5):773-8. doi:10.1038/nn.3983

\section{REFERENCES}

Are previously written articles that have additional details regarding the science experiments performed.

\section{REFERENCES}

1. Noble, K. G., Houston, S. M., Brito, N. H., Bartsch, H., Kan, E., Kuperman, J. M., et al. 2015. Family income, parental education and brain structure in children and adolescents. Nat. Neurosci. 18(5):773-8. doi:10.1038/nn.3983 
2. Sowell, E. R., Peterson, B. S., Thompson, P. M., Welcome, S. E., Henkenius, A. L., and Toga, A. W. 2003. Mapping cortical change across the human life span. Nat. Neurosci. 6(3):309-15. doi:10.1038/nn1008

3. Scholz, J., Klein, M. C., Behrens, T. E., and Johansen-Berg, H. 2009. Training induces changes in white-matter architecture. [Research Support, Non-U.S. Gov't]. Nat. Neurosci. 12(11):1370-1. doi:10.1038/nn.2412

4. Diamond, M. C. 2001. Response of the brain to enrichment. An. Acad. Bras. Cienc. 73(2):211-20. doi:10.1590/S0001-37652001000200006

5. Simmonds, D., Goldberg, M., and Luna, B. 2014. Building the roads in the city of your brain. Front. Young Minds 2:17. doi:10.3389/frym.2014.00017

6. Herting, M. M., and Nagel, B. J. 2012. Aerobic fitness relates to learning on a virtual Morris Water Task and hippocampal volume in adolescents. [Research Support, N.I.H., Extramural Research Support, Non-U.S. Gov't]. Behav. Brain Res. 233(2):517-25. doi:10.1016/j.bbr.2012.05.012

7. Vanderschuren, L. J., Niesink, R. J., and Van Ree, J. M. 1997. The neurobiology of social play behavior in rats. [Research Support, Non-U.S. Gov't Review]. Neurosci. Biobehav. Rev. 21(3):309-26. doi:10.1016/S0149-7634(96)00020-6

8. Milteer, R. M., Ginsburg, K. R, and Council on Communications and Media; Committee on Psychosocial Aspects of Child and Family Health. 2012. The importance of play in promoting healthy child development and maintaining strong parent-child bond: focus on children in poverty. Pediatrics 129(1):e204-13. doi:10.1542/peds.2011-2953

SUBMITTED: 03 February 2016; ACCEPTED: 04 August 2016; PUBLISHED ONLINE: 19 August 2016.

EDITED BY: Sabine Kastner, Princeton University, USA

CITATION: Uban K, Herting M and Sowell ER (2016) Can Money Buy You a Better Brain? What Do You Think? Front. Young Minds 4:13. doi:10.3389/frym.2016.00013

CONFLICT OF INTEREST STATEMENT: The authors declare that the research was conducted in the absence of any commercial or financial relationships that could be construed as a potential conflict of interest.

COPYRIGHT (C) 2016 Uban, Herting and Sowell. This is an open-access article distributed under the terms of the Creative Commons Attribution License (CC BY). The use, distribution and reproduction in other forums is permitted, provided the original author(s) or licensor are credited and that the original publication in this journal is cited, in accordance with accepted academic practice. No use, distribution or reproduction is permitted which does not comply with these terms. 


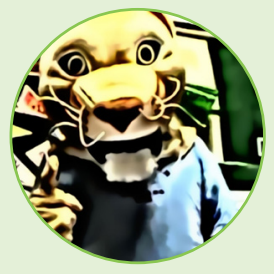

\section{REVIEWED BY}

\section{CARPENTER COMMUNITY CHARTER SCHOOL, 10-11 YEARS OLD}

Room 25 is composed of a heterogeneous grouping of 29 multi-ethnic students who participates in LAUSD's SAS Program (Schools for Advanced Studies), with clusters of gifted, English language learner, and those with special needs. Age ranges from 10 to 11 years old who are motivated to learn new and exciting concepts. Students are exposed to differentiated curriculum over the course of the school year to develop critical and creative thinking. Our motto: cultivating young minds for a modern world.

\section{AUTHORS}

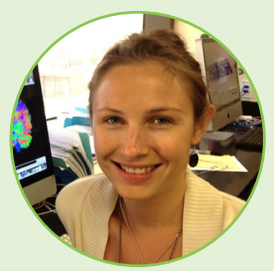

\section{KRISTINA UBAN}

I am Neuroscientist at Children's Hospital Los Angeles. I am a postdoctoral researcher, which means that I have a doctorate degree $(\mathrm{PhD})$ and am working under the mentorship of a professor until I become a professor. My postdoctoral mentor is Dr. Elizabeth R. Sowell (co-author on this article). I am fascinated with how experience (or the environment) early in life affects the developing brain. I am also interested in the mechanisms of how the environment affects the developing brain (in other words, understanding how the outside environment gets "under the skin" and into the brain). When I am not studying the brain, you may find me having fun with my family and friends through hiking, camping, traveling, playing card/board games, playing music and improvising song lyrics, or cooking together.

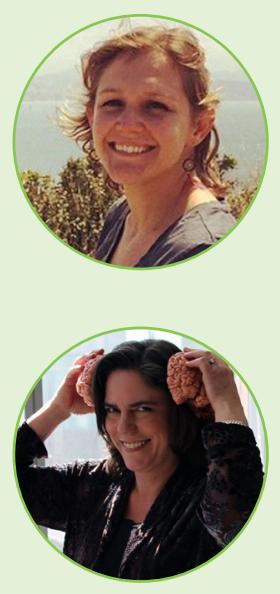

\section{MEGAN HERTING}

I am a neuroscientist studying how our brains grow and change over time. I am also interested in how the activities we decide to do, such as exercise, influence how our brains develop. It excites me that our brains always seem to be adapting to the world around us! When I am not studying the brain, I love to explore new places and enjoy mother nature.

\section{ELIZABETH R. SOWELL}

I am a neuroscientist and a professor who uses brain imaging to understand how the brain develops in kids. It fascinates me how all the things that are in our environment can change the way our brains develop, and how our brains control how we learn new things. I love to make colorful pictures of brains that help explain how they work and change. When I am not looking at kid's brains, I like traveling with my family to foreign countries and painting pictures of colorful flowers. *esowell@chla.usc.edu 